\title{
TWENTY-FIRST ANNUAL LIST OF PAPERS
}

\author{
READ BEFORE THE AMERICAN MATHEMATICAL SOCIETY AND \\ SUBSEQUENTLY PUBLISHED, INCLUDING REFERENCES \\ TO THE PLACES OF THEIR PUBLICATION.
}

Bennetr, E. R. Primitive Groups with a Determination of the Primitive Groups of Degree 20. Read (Southwestern Section) Nov. 26, 1910. American Journal of Mathematics, vol. 34, No. 1, pp. 1-20; Jan., 1912.

Bernstein, B. A. See Leuschner, A. O.

BiLl, E. G. An Existence Theorem for a Problem of the Calculus of Variations in Space. Read Dec. 30, 1908. Transactions of the American Mathematical Society, vol. 13, No. 1, pp. 50-58; Jan., 1912.

BirkнoFf, G. D. On the Solutions of Ordinary Linear Homogeneous Differential Equations of the Third Order. Read Feb. 26, 1910. Annals of Mathematics, ser. 2, vol. 12, No. 3, pp. 103-127; April, 1911.

Buiss, G. A. A Generalization of Weierstrass's Preparation Theorem for a Power Series in Several Variables. Read Sept. 13, 1911. Transactions of the American Mathematical Society, vol. 13, No. 2, pp. 133-145; April, 1912.

A New Proof of the Existence Theorem for Implicit Functions. Read Oct. 28, 1911. Bulletin of the American Mathematical Society, vol. 18, No. 4, pp. 175-179; Jan., 1912.

Bôcher, M. The Published and Unpublished Work of Charles Sturm on Algebraic and Differential Equations. Read April 28, 1911. Bulletin of the American Mathematical Society, vol. 18, No. 1, pp. 1-18; Oct., 1911.

Bowden, J. The Russian Peasant Method of Multiplication. Read Feb. 25, 1911. New York, The Macmillan Company, 1912. 5 pp.

Brenke, W. C. Transformation of Series by Means of Functions Admitting a Recurrent Relation. Read (Southwestern Section) Nov. 28, 1908. Annals of Mathematics, ser. 2, vol. 13, No. 1, pp. 40-51; Sept., 1911.

Brown, E. W. On the Sum of a Certain Triple Series. Read Dec. 27, 1907, and Oct. 28, 1911. Annals of Mathematics, ser. 2, vol. 13, No. 3 , pp. 129-136; March, 1912.

Burgess, H. T. The Circular Numbers for a Plane Curve. Read (Chicago) Dec. 29, 1910. Annals of Mathematics, ser. 2, vol. 13, No. 3, pp. 123-128; March, 1912.

CAJori, F. On Michel Rolle's Book "Méthode pour Résoudre les Egalitez" and the History of Rolle's Theorem. Read Sept. 12, 1911. Bibliotheca Mathematica, ser. 3, vol. 11, No. 4, pp. 300-313; Nov., 1911.

-. On the Spanish Symbol U for Thousands. Read (Chicago) April 6, 1912. Bibliotheca Mathematica, ser. 3, vol. 12, No. 2, pp. 133-134; May, 1912. 
Camp, B. H. Series of Laplace's Functions. Read Oct. 28, 1911. Bulletin of the American Mathematical Society, vol. 18, No. 5, pp. 236-243; Feb., 1912.

Carmichael, R. D. The General Theory of Linear $q$-Difference Equations. Read April 28, 1911. American Journal of Mathematics, vol. 34, No. 2, pp. 147-168; April, 1912.

A Generalization of Cauchy's Functional Equations. Read Oct. 28, 1911. American Mathematical Monthly, vol. 18, No. 11, pp. 198203; Nov., 1911.

- On Composite Numbers $P$ which Satisfy the Fermat Congruence $a^{P-1} \equiv 1 \bmod P$. Read Oct. 28, 1911. American Mathematical Monthly, vol. 19, No. 2, pp. 22-27; Feb., 1912.

Chapman, S. A Note on the Theory of Summable Integrals. Read Dec. 28, 1910. Bulletin of the American Mathematical Society, vol. 18, No. 3, pp. 111-117; Dec., 1911.

Clements, G. R. Implicit Functions Defined by Equations with Vanishing Jacobian. Read April 29, 1911. Bulletin of the American Mathematical Society, vol. 18, No. 9, pp. 451-456; June, 1912.

Coвle, A. B. An Application of Moore's Cross-Ratio Group to the Solution of the Sextic Equation. Read Dec. 29, 1910. Transactions of the American Mathematical Society, vol. 12, No. 3, pp. 311-325; July, 1911.

Conner, J. R. Multiple Correspondences Determined by the Rational Plane Quintic Curve. Read Dec. 29, 1910. Transactions of the American Mathematical Society, vol. 13, No. 2, pp. 265-278; April, 1912.

Dickson, L. E. Linear Algebras. Read (Chicago) Dec. 29, 1910, and Dec. 29, 1911. Transactions of the American Mathematical Society, vol. 13, No. 1, pp. 59-73; Jan., 1912.

Dopd, E. L. On Ordinary Plane and Skew Curves. Read (Chicago) April 6, 1912. Bulletin of the University of Texas, Scientific Series, No. 21, pp. 1-36; March, 1912.

Drespen, A. On the Reduction of a System of Linear Differential Forms of Any Order. Read (Chicago) Dec. 29, 1911. Annals of Mathematics, ser. 2, vol. 13, No. 3, pp. 149-153; March, 1912.

Eresland, J. On Minimal Lines and Congruences in Four-Dimensional Space. Read Sept. 7, 1910. Transactions of the American Mathematical Society, vol. 12, No. 4, pp. 403-428; Oct., 1911.

Eisenhart, L. P. A Fundamental Parametric Representation of Space Curves. Read April 28, 1911. Annals of Mathematics, ser. 2, vol. 13, No. 1, pp. 17-35; Sept., 1911.

Eмcн, A. The Differential Equation of Curves of Normal Stresses in a Plane. Read April 28, 1911. Archiv der Mathematik und Physik, ser. 3, vol. 18, No. 4, pp. 316-322; Nov. 1911.

Evans, G. C. Volterra's Integral Equation of the Second Kind, with Discontinuous Kernel (Second Paper). Read Sept. 13, 1909. Transactions of the American Mathematical Society, vol. 12, No. 4, pp. 429472 ; Oct., 1911.

Fresds, J. C. A Method of Proving Certain Theorems Relating to Rational Functions Which are Adjoint to an Algebraic Equation for a Given Value of the Independent Variable. Read Dec. 28, 1910. Transactions of the American Mathematical Society, vol. 13, No. 2, pp. 164-174; April, 1912. 
Fite, W. B. Irreducible Homogeneous Linear Groups of Order $p^{m}$ and Degree $p$ or $p^{2}$. Read Feb. 25, 1911. Bulletin of the American Mathematical Society, vol. 18, No. 3, pp. 117-121; Dec., 1911.

Ford, W. B. Conditions Suffisantes pour qu'une Fonction Admette un Développement Asymptotique. Read April 29, 1911. Bulletin de la Société Mathématique de France, vol. 39, No. 4, pp. 347-352; 1911.

Gillespie, D. C. Definite Integrals Containing a Parameter. Read Feb. 25, 1911. Bulletin of the American Mathematical Society, vol. 18, No. 8, pp. 379-384; May, 1912.

GlenN, O. E. On Semi-Discriminants of Ternary Forms. Read Dec. 29, 1910. Transactions of the American Mathematical Society, vol. 12, No. 3, pp. 367-374; July, 1911.

Hedrick, E. R. On Properties of a Domain for Which Any Derived Set is Closed. Read (Southwestern Section) Nov. 27, 1909. Transactions of the American Mathematical Society, vol. 12, No. 3, pp. 285-294; July, 1911.

Hodgson, J. E. Orthocentric Properties of the Plane Directed $n$-Line. Read Feb. 24, 1912. Transactions of the American Mathematical Society, vol. 13, No. 2, pp. 199-231; April, 1912.

Huntington, E. V. A New Approach to the Theory of Relativity. Read Oct. 28, 1911. Festschrift Heinrich Weber, Teubner, Leipzig, pp. 147-169; March, 1912. Also Philosophical Magazine, ser. 6, vol. 23, No. 4, pp. 494-513; April, 1912.

Hurwitz, W. A. Note on Mixed Linear Integral Equations. Read Sept. 12, 1911. Bulletin of the American Mathematical Society, vol. 18, No. 6, pp. 291-294; March, 1912.

Karpinski, L. C. An Italian Algebra of the Fifteenth Century. Read April 29, 1911. Bibliotheca Mathematica, ser. 3, vol. 11, No. 3, pp. 209-219; Aug., 1911.

- The Algebra of Abu Kamil Shoja ben Aslam. Read Sept. 12, 1911. Bibliotheca Mathematica, ser. 3, vol. 12, No. 1, pp. 40-55; Jan., 1912.

KeLLOGG, O. D. Harmonic Functions and Green's Integral. Read (Chicago) Dec. 28, 1906, and (Southwestern Section) Nov. 26, 1910. Transactions of the American Mathematical Society, vol. 13, No. 1, pp. 109-132; Jan., 1912.

KeYser, C. J. A Sensuous Representation of Paths that Lead from the Inside to the Outside of an Ordinary Sphere in Point Space of Four Dimensions without Penetrating the Surface of the Sphere. Read April 28, 1911. Bulletin of the American Mathematical Society, vol. 18, No. 1, pp. 18-22; Oct., 1911.

LANDAU, E. Ueber eine idealtheoretische Funktion. Read Sept. 12, 1911. Transactions of the American Mathematical Society, vol. 13, No. 1, pp. 1-21; Jan., 1912.

Lefschetz, S. On Remarkable Points of Curves. Read Feb. 24, 1912. American Mathematical Monthly, vol. 19, No. 2, pp. 27-28; Feb., 1912.

- On the $V_{3}{ }^{3}$ with Five Nodes of the Second Species in $S_{4}$. Read April 27, 1912. Bulletin of the American Mathematical Society, vol. 18, No. 8, pp. 384-386; May, 1912.

Lehmer, D. N. On the Arithmetical Theory of Pencils of Binary Quadratic Forms. Read (San Francisco) Sept. 25, 1909. American Journal of Mathematics, vol. 34, No. 1, pp. 21-30; Jan., 1912. 
Lennes, N. J. Curves in Non-Metrical Analysis Situs with an Application in the Calculus of Variations. Read (Chicago) Dec. 29, 1905. American Journal of Mathematics, vol. 33, No. 3, pp. 287-326; July, 1911. Duality in Projective Geometry. Read Feb. 25, 1911. Annals of Mathematics, ser. 2, vol. 13, No. 1, pp. 11-16; Sept., 1911. In part also under the title: A Set of Independent Assumptions for Projective Geometry. American Mathematical Monthly, vol. 18, No. 10, pp. 174-182; Oct., 1911.

- A Direct Proof of the Theorem that the Number of Terms in the Expansion of an Infinite Determinant is of the Same Potency as the Continuum. Read Feb. 25, 1911. Bulletin of the American Mathematical Society, vol. 18, No. 1, pp. 22-24; Oct., 1911.

- A Necessary and Sufficient Condition for the Uniform Convergence of a Certain Class of Infinite Series. Read Feb. 25, 1911. Bulletin of the American Mathematical Society, vol. 18, No. 2, pp. 66-70; Nov., 1911, and No. 4, pp. 200-201; Jan., 1912.

Leuschner, A. O., and Bernstein, B. A. Note on the Graphical Solutions of the Fundamental Equations in the Short Methods of Determining Orbits. Read (San Francisco) Oct. 28, 1911. Bulletin of the American Mathematical Society, vol. 18, No. 6, pp. 294-298; March, 1912.

Lipke, J. Natural Families of Curves in a General Curved Space of $n$ Dimensions. Read Sept. 13, 1909, and Dec. 29, 1910. Transactions of the American Mathematical Society, vol. 13, No. 1, pp. 77-95; Jan., 1912.

Longley, W. R. Points of Indeterminate Slope on the Discriminant Locus of an Ordinary Differential Equation. Read Dec. 28, 1910. Annals of Mathematics, ser. 2, vol. 13, No. 2, pp. 55-70; Dec., 1911

_- Proof of a Theorem Due to Picard. Read April 27, 1912. Bulletin of the American Mathematical Society, vol. 18, No. 10, pp. 493-496; July, 1912.

Lovetw, E. O. Generalizations of the Problem of Several Bodies, its Inversion, and an Introductory Account of Recent Progress in the Solution. Read Sept. 1, 1903; Sept. 5, 1907; Dec. 27, 1907; Dec. 30, 1908. Quarterly Journal of Pure and Applied Mathematics, vol. 42, Nos. 3-4, pp. 252-315; April-July, 1911.

McKelvey, J. V. The Groups of Birational Transformations of Algebraic Curves of Genus 5. Read Dec. 29, 1909. American Journal of Mathematics, vol. 34, No. 2, pp. 115-146; April, 1912.

MacMillan, W. D. An Existence Theorem for Periodic Solutions. Read April 29, 1911. Transactions of the American Mathematical Society, vol. 13, No. 2, pp. 146-158; April, 1912.

Manning, W. A. On the Limit of the Degree of Primitive Groups. Read (San Francisco) Feb. 23, 1907, and (Chicago) Dec. 31, 1909. Transactions of the American Mathematical Society, vol. 12, No. 4, pp. 375-386; Oct., 1911.

Mrles, E. J. The Absolute Minimum of a Definite Integral in a Special Field. Read Dec. 28, 1910. Transactions of the American Mathematical Society, vol. 13, No. 1, pp. 35-49; Jan., 1912.

Miller, G. A. Abstract Definitions of all the Substitution Groups Whose Degrees do not Exceed Seven. Read (Southwestern Section) Nov. 26, 1910. American Journal of Mathematics, vol. 33, No. 4, pp. 363-372; Oct., 1911. 
On the Use of the Co-Sets of a Group. Read (Chicago) Dec. 29, 1910. Transactions of the American Mathematical Society, vol. 12, No. 3, pp. 326-334; July, 1911.

- Number of the Abelian Subgroups in the Possible Groups of Order $2^{m}$. Read Feb. 25, 1911. Messenger of Mathematics, vol. 41, No. 2, pp. 28-31; June, 1911.

- Isomorphisms of a Group Whose Order is a Power of a Prime. Read April 28, 1911. Transactions of the American Mathematical Society, vol. 12, No. 4, pp. 387-402; Oct., 1911.

- Note on the Maximal Cyclic Subgroups of a Group of Order $p^{m}$. Read (San Francisco) Oct. 28, 1911. Bulletin of the American Mathematical Society, vol. 18, No. 4, pp. 189-191; Jan., 1912.

- A Third Generalization of the Groups of the Regular Polyhedrons. Read Sept. 12, 1911. Annals of Mathematics, ser. 2, vol. 13, No. 3, pp. 103-113; March, 1912.

Mitchell, U. G. Geometry and Collineation Groups of the Finite Projective Plane $P G\left(2,2^{2}\right)$. Read April 28, 1911. Lawrence, Kan., 1912.

Moore, C. L. E. Conjugate Directions on a Hypersurface in a Space of Four Dimensions and Some Allied Curves. Read Dec. 29, 1910. Annals of Mathematics, ser. 2, vol. 13, No. 2, pp. 89-102; Dec., 1911.

- Surfaces in Hyperspace Which Have a Tangent Line with ThreePoint Contact Passing through Each Point. Read Dec. 27, 1911. Bulletin of the American Mathematical Society, vol. 18, No. 6, pp. 284-290; March, 1912.

- See Phillirs, H. B.

Moore, E. H. On the Foundations of the Theory of Linear Integral Equations. Read Sept. 5-8, 1906. Bulletin of the American Mathematical Society, vol. 18, No. 7, pp. 334-362; April, 1912.

Moone, R. L. A Note Concerning Veblen's Axioms for Geometry; Read Oct. 26, 1907. Transactions of the American Mathematical Society, vol. 13, No. 1, pp. 74-76; Jan., 1912.

Monitz, R. E. On the Cubes of Determinants of the Second, Third, and Higher Orders. Read (San Francisco) April 8, 1911. Bulletin of the American Mathematical Society, vol. 18, No. 4, pp. 182-189; Jan., 1912.

Moulton, F. R. The Problem of the Spherical Pendulum from the Standpoint of Periodic Solutions. Read (Chicago) April 9, 1910. Rendiconti del Circolo Matematico di Palermo, vol. 32, No. 3, pp. 338364; Nov.-Dec., 1911.

- A Class of Periodic Orbits of Superior Planets. Read April 29, 1911. Transactions of the American Mathematical Society, vol. 13, No. 1, pp. 96-108; Jan., 1912.

- On Certain Expansions of Elliptic, Hyperelliptic, and Related Periodic Functions. Read April 29, 1911. American Journal of Mathematics, vol. 34, No. 2, pp. 177-202; April, 1912.

NeIKIRK, L. I. A Theorem on $(m, n)$ Correspondences. Read (Chicago) April 8, 1910. Annals of Mathematics, ser. 2, vol. 13, No. 1, pp. 52-54; Sept., 1911.

Noble, C. A. Characteristics of Two Partial Differential Equations of Order One. Read (San Francisco) Feb. 26, 1910. Annals of Mathematics, ser. 2, vol. 12, No. 4, pp. 179-184; July, 1911. 
Osqood, W. F. A Condition that a Function in a Projective Space be Rational. Read Feb. 24, 1912. Transactions of the American Mathematical Society, vol. 13, No. 2, pp. 159-163; April, 1912.

Phillips, H. B., and Moore, C. L. E. An Algebra of Plane Projective Geometry. Read Dec. 27, 1911. Proceedings of the American Academy of Arts and Sciences, vol. 47, No. 20, pp. 737-790; March, 1912.

Ponzer, E. W. The Calculus in Technical Literature. Read (San Francisco) April 8, 1911. Science, New Ser., vol. 34, No. 869, pp. 225-234; Aug. 25, 1911.

Powers, R. E. The Tenth Perfect Number. Read Oct. 28, 1911. American Mathematical Monthly, vol. 18, No. 11, pp. 195-197; Nov., 1911.

Ranum, A. On the Principle of Duality in the Geometry of the Sphere. Read Feb. 26, 1910. American Journal of Mathematics, vol. 34, No. 1, pp. 31-46; Jan., 1912.

Richardson, R. G. D. Das Jacobische Kriterium der Variationsrechnung und die Oszillationseigenschaften linearer Differentialgleichungen 2. Ordnung. Read Dec. 29, 1909. Mathematische Annalen, vol. 71, No. 2, pp. 214-232; Sept., 1911.

- Theorems of Oscillation for Two Linear Differential Equations of the Second Order with Two Parameters. Read Dec. 28, 1910, and April 28, 1911. Transactions of the American Mathematical Society, vol. 13, No. 1, pp. 22-34; Jan., 1912.

Row, E. D., Jr. A New Invariantive Function. Read Sept. 7, 1910. Jahresbericht der Deutschen Mathematiker-Vereinigung, vol. 20, Nos. 9-10, pp. 343-353; Sept.-Oct., 1911.

Roever, W. H. The Southerly Deviation of Falling Bodies. Read (Southwestern Section) Nov. 27, 1909, and Nov. 26, 1910; April 29, 1911. Transactions of the American Mathematical Society, vol. 12, No. 3, pp. 335-353; July, 1911.

Rowe, J. E. Important Covariant Curves and a Complete System of Invariants of the Rational Quartic Curve. Read Sept. 6, 1910 Transactions of the American Mathematical Society, vol. 12, No. 3, pp. 295-310; July, 1911.

SAFFord, F. H. An Identical Transformation of the Elliptic Element in the Weierstrass Form. Read April 29, 1911. Bulletin of the American Mathematical Society, vol. 18, No. 6, pp. 279-284; March, 1912.

Schweitzer, A. R. Concerning Linear Projective Order. Read (Chicago) Jan. 1, 1910. American Journal of Mathematics, vol. 34, No. 2, pp. 169-176; April, 1912.

- On a Functional Equation. Read Oct. 28, 1911. Bulletin of the American Mathematical Society, vol. 18, No. 6, pp. 299-302; March, 1912.

SisAm, C. H. On Algebraic Hyperconical Connexes in Space of $r$ Dimensions. Read April 29, 1911. Atti della R. Accademia delle Scienze di Torino, vol. 46, pp. 371-377; 1911.

SlobIN, H. L. On Plane Quintic Curves. Read (Chicago) Dec. 30, 1910. Minneapolis, University of Minnesota, no date. 
Sмiтн, W. M. Simply Infinite Systems of Plane Curves. A Study of Isogonals, Equitangentials and Other Families of Trajectories. Read Dec. 27, 1911; Easton, Pa., 1912.

SNYDER, V. An Application of a $(1,2)$ Quaternary Correspondence to the Weddle and Kummer Surfaces. Read Dec. 28, 1910. Transactions of the American Mathematical Society, vol. 12, No. 3, pp. 354366; July, 1911.

- The Involutorial Birational Transformation of the Plane, of Order 17. Read Sept. 6, 1910. American Journal of Mathematics, vol. 33, No. 4, pp. 327-336; Oct., 1911.

- Periodic Quadratic Transformations in the Plane. Read Sept. 12, 1911. Annals of Mathematics, ser. 2, vol. 13, No. 3, pp. 140-148; March, 1912.

Stager, H. W. On Numbers which Contain no Factors of the Form $p(k p+1)$. Read (San Francisco) Feb. 27, 1909. University of California Publications in Mathematics, vol. 1, No. 1, pp. 1-26; June, 1912.

UrNer, S. E. Certain Singularities of Point Transformations in Space of Three Dimensions. Read Feb. 24, 1912. Transactions of the American Mathematical Society, vol. 13, No. 2, pp. 232-264; April, 1912.

Veblen, O. On the Definition of Multiplication of Irrational Numbers. Read Sept. 13, 1911. American Journal of Mathematics, vol. 34, No. 2, pp. 211-214; April, 1912.

Webster, A. G. On a New Mixed Problem of the Partial Differential Equation of Telegraphy. Read Sept. 13, 1911. Bulletin of the American Mathematical Society, vol. 18, No. 5, pp. 244-253; Feb., 1912.

Westlund, J. Primitive Roots of Ideals in Algebraic Number Fields. Read (Chicago) Dec. 30, 1905, and Dec. 29, 1910. Mathematische Annalen, vol. 71, No. 2, pp. 246-250; Sept., 1911.

White, M. B. The Dependence of Focal Points upon Curvature for Problems of the Calculus of Variations in Space. Read (Southwestern Section) Dec. 2, 1911. Transactions of the American Mathematical Society, vol. 13, No. 2, pp. 175-198; April, 1912.

Wilczynski, E. J. Sur la Théorie Générale des Congruences. Read (Chicago) April 8, 1910. Mémoires de l'Académie Royale de Belgique, Classe des Sciences, ser. 2, vol. 3, No. 5, pp. 1-86; June, 1911.

- One-Parameter Families and Nets of Plane Curves. Read (Chicago) Dec. 29, 1910. Transactions of the American Mathematical Society, vol. 12 , No. 4, pp. 473-510; Oct., 1911. 